\title{
Ductilidad del acero de armar con diferentes grados de corrosión, aplicando el criterio de 'acero equivalente'
}

\section{Ductility of reinforcing steel with different degrees of corrosion and the 'equivalent steel' criterion}

\author{
E. Moreno Fernández ${ }^{(*)}$, A. Cobo Escamilla(*), M. Fernández Cánovas ${ }^{(* *)}$
}

Recepción/Received: 17-VII-06

Aceptación/Accepted: 25-IX-06

\section{RESUMEN}

Uno de los efectos más significativos de la corrosión de la armadura en las estructuras de hormigón armado es la disminución de las propiedades relacionadas con la ductilidad del acero.

La ductilidad del acero engloba un conjunto de propiedades que condicionan el comportamiento de las estructuras de hormigón armado y es necesario considerar en el recálculo de estructuras ya corroídas, hasta el punto de condicionar en muchas ocasiones la metodología del análisis.

En este trabajo experimental se estudia la variación de la ductilidad de barras de acero embebidas en hormigón que sufren un proceso de corrosión acelerada; se realizan consideraciones acerca de la metodología más conveniente de análisis estructural a realizar según los resultados obtenidos.

Palabras clave: estructuras de hormigón, corrosión de armaduras, ductilidad, acero equivalente.

\section{SUMMARY}

One of the most significant effects of reinforcing steel corrosion on reinforced concrete structures is the decline in the ductility-related properties of the steel.

Such properties condition the behaviour of reinforced concrete structures and must be taken into account when re-engineering corroded members, for even the analytical approach itself may be determined on these grounds.

The present experimental study addresses the variation in the ductility of concrete-embedded steel bars when exposed to accelerated corrosion; the results serve as a basis for a discussion of the most suitable methodology for structural analysis.

Keywords: concrete structures, reinforcement corrosion, ductility, equivalent steel.

\section{INTRODUCCIÓN}

El avance que se está produciendo en el conocimiento del comportamiento de las estructuras de hormigón armado implica la aparición y la aceptación de métodos de análisis que tratan de aproximarse cada vez más a los

\section{INTRODUCTION}

Progress in the understanding of the behaviour of reinforced concrete structures has depended upon the appearance and acceptance of analytical methods that attempt to provide an increasingly accurate explanation

(*) Escuela Universitaria de Arquitectura Técnica. Universidad Politécnica de Madrid (España).

(**) Escuela Técnica Superior de Ingenieros de Caminos, Canales y Puertos. Universidad Politécnica de Madrid (España). 
fenómenos observados en las estructuras reales. Al mismo tiempo, los nuevos procedimientos de cálculo exigen nuevas prestaciones en las estructuras y en sus materiales constituyentes. En concreto, la aplicación de métodos de análisis basados en redistribuciones respecto del cálculo elástico y lineal exige estructuras con suficiente capacidad de giro en las secciones más solicitadas. Para ello es necesario que las armaduras cumplan con unas características que se pueden englobar bajo el término de ductilidad.

Una estructura dúctil permite redistribuir los efectos de las acciones; cuando en una sección se alcanza su máxima capacidad portante, otra puede asumir más carga, pero para ello se requiere que la primera de las secciones pueda seguir deformándose, al igual que el resto de la estructura.

En fase de proyecto de obra nueva, la ductilidad permite distintas posibilidades de análisis estructural, consiguiéndose armados más cómodos de realizar en obra. Además, una estructura dúctil soporta mayores cargas de colapso, permitiendo, gracias a las mayores deformaciones, predecir riesgos en casos especiales.

En fase de proyecto, en zona sísmica, la ductilidad permite absorber mayor cantidad de energía, siendo en este caso de importancia capital.

Las dos cuestiones anteriores son suficientemente conocidas y han sido difundidas en multitud de medios, tanto nacionales como internacionales (1-4). En este trabajo se pretende dar un enfoque nuevo al tema. En EHA ya construidas interesa analizar la estructura con redistribución de solicitaciones, para poder comparar los valores de resistencias últimas, no con un único valor obtenido en régimen elástico y lineal, sino con una banda de valores, centrada en los valores obtenidos en régimen elástico y lineal y de una apertura igual al doble del valor de la máxima capacidad de redistribución. De este modo, las posibilidades de "sacar adelante" una estructura ya construida son mucho mayores.

Para poder realizar este análisis interesa en primer lugar que se tenga la posibilidad de redistribuir $y$, en segundo lugar, interesa que ésta sea lo mayor posible.

Las normas europeas y otros documentos usualmente empleados en el análisis de estructuras consideran la ductilidad del acero como uno de los parámetros a considerar para obtener la capacidad de distribuir solicitaciones, pero no hay un consenso en cuanto a los valores a adoptar como máxima redistribución permitida ni los valores exigidos para poder redistribuir esta cantidad $(5,6)$.

Por lo tanto, conocer la variación de la ductilidad en armaduras corroídas adquiere una gran importancia en las operaciones de recálculo de estructuras. of the phenomena observed in actual structures. At the same time, new engineering procedures are making new demands on structures and their constituent materials. Specifically, the application of analytical methods based on moment redistribution calls for structures with sufficient rotation capacity in the portions under greatest stress. Reinforcement must, for this reason, meet a series of requirements that can be enveloped in the term ductility.

In ductile structures the effect of actions can be redistributed; when the maximum load carrying capacity is reached in one section, another can bear a higher load, but only if the former section and the structure as a whole can accommodate further deformation.

In new construction, various structural design methods may be used to analyze ductility and obtain the most convenient reinforcement layout for on-site works. Moreover, ductile structures have higher ultimate load values and in the event of special circumstances their risks are more predictable thanks to their greater deformability.

Ductility also provides for higher levels of energy absorption, a concern of cardinal importance in seismic area design.

The foregoing issues are well understood and have been the object of a host of articles in both national and international journals (1-4). The present paper aims to look at the question from a new angle. The analysis of existing $R C$ structures should address moment redistribution to be able to compare ultimate strength values, rather than to a single value obtained with elastic linear models, to a range of values centred on the elastic and linear values obtained and defining an interval equal to double the value of the maximum redistribution capacity. This greatly enhances the possibility of "saving" a standing structure.

Such an analysis should determine, first, whether moment redistribution is possible and second, the scope of the redistribution, which should be a extensive as possible.

In European and other codes commonly used in structural analysis, steel ductility is regarded to be one of the instrumental parameters for defining moment distribution capacity, but no consensus has yet been reached about the maximum redistribution that should be allowed or the minimum values required to be able to proceed to such redistribution $(5,6)$.

Consequently, the ascertainment of corroded reinforcement ductility is of key importance in structural re-engineering. 


\section{REDISTRIBUCIÓN DE SOLICITACIONES Y REQUERIMIENTOS DE DUCTILIDAD}

La Instrucción de Hormigón Estructural EHE (7) fija las condiciones de ductilidad del acero en función del cumplimiento de unos valores mínimos de:

- (fs/fy) Relación entre la tensión máxima unitaria del acero a tracción y el límite elástico del mismo. Este cociente representa un índice de la reserva de resistencia que tiene un acero, después de alcanzar el límite elástico. Cuanto más alta es esta relación, mayor es el margen de seguridad frente a rotura. Su influencia en la ductilidad de la estructura viene dada por la mejora en el comportamiento de las rótulas plásticas. Desde el punto de vista del cálculo, el valor fs/fy suele limitarse superior e inferiormente: Por una parte, la capacidad de un elemento para desarrollar un comportamiento dúctil es función de la longitud de la rótula plástica que se forma, y ésta, entre otras cosas, de la relación fs/fy; así el valor mínimo que fija la Norma UNE 36065:1999 EX (8) es igual a 1,20. Por otra, durante la formación de la rótula plástica, el acero al deformarse puede alcanzar su máxima capacidad resistente a flexión, lo que conlleva un aumento de los esfuerzos asociados (cortante, tracción o compresión, etc.). Para evitar cualquier forma de rotura frágil, como un fallo por anclaje, en la Norma UNE 36065: 1999 EX se limita superiormente la relación a 1,35.

- $\left(\mathbf{A}_{\mathbf{5}}\right)$ Alargamiento remanente de rotura. Es el incremento de longitud, expresado en porcentaje, producido en la probeta de acero una vez finalizado el ensayo de tracción. Se determina juntando los dos trozos de material ensayado generados tras la rotura y midiendo, sobre una longitud previamente determinada, múltiplo del diámetro de la sección inicial, el aumento de longitud expresado en porcentaje. El valor de dicho múltiplo varía de unos países a otros. En España se toma igual a cinco. La ductilidad del acero aumenta con el incremento de $A_{5}$.

El Código Modelo CEB-FIP (CM-90) (5) y el Eurocódigo 2 (EC-2) (6) clasifican al acero en varios grados de ductilidad en función de dos parámetros que son el cociente entre los dos valores de tensión anteriores y el alargamiento bajo carga máxima $\varepsilon_{\text {máx }}$ (deformación uniforme experimentada por la probeta de acero en el ensayo de tracción cuando se somete a la carga máxima). Se expresa como un porcentaje de la longitud inicial entre dos puntos previamente marcados de la probeta. Cuanto mayor es este alargamiento, más dúctil es el acero (Tabla 1).

\section{EL CONCEPTO DE ACERO EQUIVALENTE}

La ductilidad de la armadura tiene una influencia decisiva en la ductilidad de las estructuras de hormigón armado. Ya se ha visto que documentos como CM-90 o

\section{MOMENT REDISTRIBUTION AND DUCTILITY REQUIREMENTS}

The Spanish structural concrete code, EHE (7), lays down steel ductility requirements in terms of compliance with minimum values of:

- (fs/fy) ratio between the ultimate and yield strength of the steel. This ratio represents a steel's reserve strength over and above its yield strength, i.e., beyond its elastic limit. The higher this ratio, the higher is the margin of safety against fracture, for a higher ratio implies better plastic hinge performance and therefore greater ductility. From the standpoint of structural engineerng, fs/fy is generally bounded by an upper and a lower limit. On the one hand, the ductility of a member depends on the length of the plastic hinge formed, which in turn depends on the fs/fy ratio, among others. Spanish standard UNE 36065:1999 EX (8) specifies a minimum value of 1.20 for this ratio. On the other, the steel may attain its maximum bending strength, with the concomitant rise in the associated (shear, tensile or compressive) stress during plastic hinge formation. It is for this reason that standard UNE 36065: 1999 EX limits the $f s / f y$ ratio to a ceiling value of 1.35 to prevent any manner of brittle fracture, such as anchorage failure.

- $\left(A_{5}\right)$ shear to fracture. This is the increase in length, expressed as a percentage, measured in a steel specimen after the tensile test. It is found by joining the two pieces of material tested after fracture and measuring them against a previously established length -a multiple of the diameter of the initial section- to determine the increase in length expressed as a percentage. The value of that multiple varies from one country to another. In Spain it is five. Steel ductility increases with $A_{5}$.

The CEB-FIP Model Code (CM-90) (5) and Eurcode 2 (EC-2) (6) classify steel into several grades of ductility depending on two parameters: the fs/fy ratio and elongation at maximum loading, $\varepsilon_{\max }$ (uniform strain on the steel specimen during the tensile test when subjected to the maximum load). It is expressed as a percentage of the initial length between two previously defined points on the specimen. The greater the elongation, the more ductile the steelm (Table 1).

\section{EQUIVALENT STEEL. THE CONCEPT}

Reinforcement ductility has a decisive effect on the overall ductility of reinforced concrete structures. Codes such as EC-2 and CM-90 classify steel by type depending 
Tabla 1 / Table 1

Capacidad de redistribución permitida por diferentes normas y requisitos de ductilidad del acero Moment redistribution allowed in concrete codes and specifications for special ductility steel

\begin{tabular}{|c|c|c|}
\hline Código / Code & Redistribución de momentos / Moment redistribution & Especificaciones de ductilidad / Ductility specifications \\
\hline EUROCÓDIGO 2 EC-2 1992 & $\begin{array}{l}\text { a) Acero de alta ductilidad (C) / High ductility steel (C) } \\
\qquad f_{\mathrm{ck}} \leq 50: \delta \geq 0,44+1,25 \mathrm{x} / \mathrm{d} \\
\mathrm{f}_{\mathrm{ck}}>50: \delta \geq 0,54+1,25 \mathrm{x} / \mathrm{d} \\
\text { Pórtico intraslacional: Máx. } 30 \% \text { / Non-sway frame: Max. 30\% } \\
\text { Pórtico-traslacional: no redistribución } \\
\text { Sway frame: no redistribution } \\
\text { b) Acero Normal (B) / Standard steel (B) } \\
\text { Máx. 15\% / Max. 15\% } \\
\text { c) Acero de baja ductilidad (A) / Low ductility steel (A) } \\
\text { Máx. 20\% / Max. 20\% }\end{array}$ & $\begin{array}{c}\text { Clase A:/ Class A: } \\
\left(\mathrm{f}_{\mathrm{s}} / \mathrm{f}_{\mathrm{y}}\right)_{\mathrm{k}} \geq 1,05 ; \varepsilon_{\max , \mathrm{k}} \geq 2,5 \% \\
\text { Clase B: / Class B: } \\
\left(\mathrm{f}_{\mathrm{s}} / \mathrm{f}_{\mathrm{y}}\right)_{\mathrm{k}} \geq 1,08 ; \varepsilon_{\max , \mathrm{k}} \geq 5,0 \% \\
\text { Clase C: / Class C: } \\
1,15 \leq\left(\mathrm{f}_{\mathrm{s}} / \mathrm{f}_{\mathrm{y}}\right)_{\mathrm{k}}<1,35 ; \varepsilon_{\max , \mathrm{k}} \geq 7,5 \%\end{array}$ \\
\hline $\begin{array}{l}\text { CEB-FIP MODEL } \\
\text { CODE } 1990\end{array}$ & $\begin{array}{l}\text { a) Ductilidad alta o normal (S y A, respectivamente) } \\
\text { a) High or standard ductility (classes } S \text { and A, respectively) } \\
\qquad f_{c k} \leq 35: d \geq 0,44+1,25 x / d \\
f_{c k}>35: d \geq 0,56+1,25 \times / d \\
\text { Pórtico intraslacional: Máx. } 25 \% \text { / Non-sway frame: Max. } 25 \% \\
\text { Pórtico traslacional: Máx.10\% / Sway frame: Max. } 10 \% \\
\text { b) Acero de baja ductilidad (B) / Low ductility steel (B) } \\
\delta \geq 0,75+1,25 \times / \text { d Máx. } 10 \% / \delta \geq 0,75+1,25 x / \text { d Max. } 10 \%\end{array}$ & $\begin{array}{c}\text { Clase B: / Class B: } \\
\left(\mathrm{f}_{\mathrm{s}} / \mathrm{f}_{\mathrm{y}}\right)_{\mathrm{k}} \geq 1,05 ; \varepsilon_{\max } \geq 2,5 \% \\
\text { Clase A:/ Class A: } \\
\left(\mathrm{f}_{\mathrm{s}} / \mathrm{f}_{\mathrm{y}}\right)_{\mathrm{k}} \geq 1,08 ; \varepsilon_{\max , \mathrm{k}} \geq 5,0 \% \\
\text { Clase } \mathrm{S}: / \text { Class } \mathrm{S}: \\
\left(\mathrm{f}_{\mathrm{s}} / \mathrm{f}_{\mathrm{y}}\right)_{\mathrm{k}} \geq 1,15 ; \varepsilon_{\max , \mathrm{k}}>6 \%\end{array}$ \\
\hline $\begin{array}{l}\text { INSTRUCCIÓN EHE } \\
\text { SPANISH EHE CODE }\end{array}$ & $\begin{array}{c}\text { Máx. } 15 \% \text { / Max. } 15 \% \\
x / d \leq 0,45\end{array}$ & $\begin{array}{l}\text { Acero de baja ductilidad / Low ductility steel } \\
\qquad \begin{array}{c}\text { B } 500 \mathrm{~T}:\left(\mathrm{f}_{\mathrm{s}} / \mathrm{f}_{\mathrm{y}}\right)_{\mathrm{k}} \geq 1,03 \\
\varepsilon_{\mathrm{u}, \mathrm{k}} \geq 8,0 \%\end{array} \\
\text { Acero de ductilidad normal / Standard ductility steel } \\
\text { B } 400 \mathrm{~S}:\left(\mathrm{f}_{\mathrm{s}} / \mathrm{f}_{\mathrm{y}}\right)_{\mathrm{k}} \geq 1,05 \\
\varepsilon_{\mathrm{u}, \mathrm{k}} \geq 14,0 \% \\
\text { B } 500 \mathrm{~S}:\left(\mathrm{f}_{\mathrm{s}} / \mathrm{f}_{\mathrm{y}}\right)_{\mathrm{k}} \geq 1,05 ; \\
\varepsilon_{\mathrm{u}, \mathrm{k}} \geq 12,0 \% \\
\text { Acero con características especiales de ductilidad } \\
\text { Special ductility steel } \\
\text { B400 SD: } 1,20 \leq\left(\mathrm{f}_{\mathrm{s}} / \mathrm{f}_{\mathrm{y}}\right)_{\mathrm{k}} \leq 1,35 ; \\
\varepsilon_{\max , \mathrm{k}} \geq 9 \% \varepsilon_{\mathrm{u}, \mathrm{k}} \geq 20,0 \% \\
\text { B500 SD:1,15 } \leq\left(\mathrm{f}_{\mathrm{s}} / \mathrm{f}_{\mathrm{y}}\right)_{\mathrm{k}} \leq 1,35 \\
\varepsilon_{\max , \mathrm{k}} \geq 8 \% \varepsilon_{\mathrm{u}, \mathrm{k}} \geq 16,0 \%\end{array}$ \\
\hline
\end{tabular}

EC-2 clasifican los aceros en distintos tipos, en función de sus características de ductilidad definida por valores mínimos de dos parámetros: el cociente entre la tensión máxima y la tensión en el límite elástico $\left(f_{t} / f_{y}\right)$ y el alargamiento bajo carga máxima $\left(\varepsilon_{\text {máx }}\right)$. Sin embargo, puede ocurrir que un determinado acero no llegue a cumplir uno de los dos requerimientos para pertenecer a una determinada clase, pero cumpla sobradamente el otro. Según los documentos anteriores, el acero en cuestión pertenecería a la clase inferior, mientras que el comportamiento experimental sugiere que el cumplimiento en exceso de uno de los valores puede compensar el otro valor $y$, debido a esto, su ductilidad fuese superior a la de un acero que cumple estrictamente con los requerimientos para pertenecer a una determinada clase. on their ductility as defined by the minimum values of two parameters: the ultimate strength-yield strength ratio $\left(f_{t} / f_{y}\right)$ and elongation under maximum loading $\left(\varepsilon_{\max }\right)$. It is nonetheless possible for a given steel to fail to meet one of the two requirements for inclusion in a certain class, while amply exceeding the specifications for the other. According to the above codes, the steel in question would be relegated to the next lower class, whereas experimental observations suggest that amply exceeding one of the values may compensate for not meeting the other and afford the steel in question greater ductility than one that complies strictly with the two requirements to belong to a certain class. 
A partir de estas consideraciones, en Europa surgió durante la década de 1990 el concepto de acero equivalente, que se puede definir como un acero que da las mismas prestaciones de ductilidad que los definidos en las clases de EC-2 o CM-90, aunque puede que no alcance alguno de los dos requerimientos mínimos exigidos.

Existen diversos criterios para definir el acero equivalente. En este trabajo vamos a analizar los correspondientes a Cosenza (9) Creazza (10) y a Ortega (1).

La definición de acero equivalente de Cosenza se basa en dos conceptos:

- Se considera a la capacidad de giro como el parámetro estructural más importante: dos aceros distintos son equivalentes si y sólo si producen la misma capacidad de rotación.

- El acero se define sólo por dos parámetros: el alargamiento bajo carga máxima y el cociente entre la tensión máxima y la tensión en el límite elástico.

Siguiendo estas ideas, la rotación plástica que es capaz de soportar una viga de hormigón armado antes del fallo, se asume como el parámetro principal para definir su comportamiento estructural, y la capacidad de rotación se supone que sólo depende de las propiedades del acero.

Se realizó un extenso análisis paramétrico para evaluar la influencia de las características del acero sobre la rotación plástica y así definir el acero equivalente.

Para el análisis paramétrico, se consideró una viga de referencia de sección $30 \times 60 \mathrm{~cm}^{2}$, longitud $6 \mathrm{~m}$, armada con $2 \varnothing 12$ y profundidad de fibra neutra $x / d=0,10$.

Se obtuvieron resultados para aceros con y sin escalón de cedencia. En la Figura 1 se ofrecen, a título de ejemplo, los resultados obtenidos para aceros sin escalón de cedencia, en los queel comportamiento tensión deformación se describió a partir de la formulación de Ramberg y Osgood [1-3]:
In light of such considerations, the concept of equivalent steel, defined to be steel having the same properties as those laid down in the EC-2 or CM-90 classes, although not necessarily meeting both minimum requirements, arose in Europe in the 1990s.

There are a number of criteria for defining equivalent steel. The present paper analyzes the ones put forward by Cosenza (9), Creazza (10) and Ortega (1).

Cosenza's definition of equivalent steel is based on two concepts:

- It regards rotation capacity to be the most important structural parameter: two different steels are equivalent only if they generate the same rotation capacity.

- Steel is defined by two parameters only: elongation under maximum loading and the ultimate strengthyield strength ratio.

Pursuant to these ideas, the plastic rotation borne by a reinforced steel beam prior to failure is assumed to be the chief parameter to define its structural behaviour and is understood to depend solely on the properties of the steel.

An extensive parametric analysis was conducted to assess the effect of steel characteristics on plastic rotation and thus define equivalent steel.

In this analysis, the reference beam was defined to have a section of $30 \times 60 \mathrm{~cm}^{2}$, a length of $6 \mathrm{~m}$ and to be reinforced with $2 \varnothing 12$ bars; the depth of the neutral fibre was set at $x / d=0.10$.

Results were found for steel with and without a definite yield point. Figure 1 shows the results for steel with no definite yield point, in which the Ramberg and Osgood formula was used to describe the stress-strain behaviour [1-3]:

$$
\varepsilon_{\mathrm{s}}=\frac{\sigma_{\mathrm{s}}}{\mathrm{E}_{\mathrm{s}}}+\left(\frac{\sigma_{\mathrm{s}}}{\mathrm{B}}\right)^{\mathrm{n}}[1] \quad \mathrm{n}=\frac{\ln \frac{\left(\varepsilon_{\mathrm{u}}-\mathrm{f}_{\mathrm{t}} / \mathrm{E}_{\mathrm{s}}\right)}{0,002}}{\ln \left(\mathrm{f}_{\mathrm{t}} / \mathrm{f}_{\mathrm{y}}\right)}
$$

$$
B=\frac{f_{y}}{0,002^{(1 / n)}}
$$

donde $f_{t}$ es la tensión de rotura y $f_{y}$ es la tensión en el límite elástico.

Los resultados de la Figura 1 muestran que todas las curvas tienden a cero para valores bajos de la deformación última del acero, independientemente del where $f_{t}$ is the ultimate strength and $f_{y}$ the yield strength.

According to the results in Figure 1, all the curves tend to zero for low values of strain to fracture, regardless of the $f_{t} / f_{y}$ ratio, and for low values of $f_{t} / f_{y}-1$, irrespective 
cociente $f_{t} / f_{y} ;$ y para valores bajos de $f_{t} / f_{y}-1$, independientemente de $\varepsilon_{u}$. Del correspondiente análisis numérico se obtuvo la siguiente expresión [4]: of $\varepsilon_{u}$. The following expression was obtained from numerical analysis [4]:

$$
\theta_{p l}=1,3 \cdot \varepsilon_{u} 0,73\left(\frac{f_{t}}{f_{y}}-1\right)^{0,92}
$$

donde $\theta_{p l}$ es la rotación plástica.

De modo que la rotación plástica es proporcional al parámetro $p$, siendo [5]:

where $\theta_{p l}$ is plastic rotation.

Hence plastic rotation is proportional to parameter $p$, where [5]:

$$
p=\varepsilon_{u} 0,73\left(\frac{f_{t}}{f_{y}}-1\right)^{0,92} \cong \varepsilon_{u}^{0,75}\left(\frac{f_{t}}{f_{y}}-1\right)^{0,9}
$$

que sólo depende de las características del acero.

A partir de estos razonamientos, Cosenza et al. sugieren que aceros caracterizados por sendas parejas de valores $\left(\varepsilon_{u}, f_{t} / f_{y}\right)$ que den el mismo valor de $p$ se definen como equivalentes.

$\mathrm{Si}$, por ejemplo, se trata de un acero sin escalón de cedencia, se introducen los límites de $f_{t} / f_{y}$ y de $\varepsilon_{u}$ que definen cada una de las clases en que se dividen los aceros según CM-90 y EC-2, y se obtiene de esta forma el valor límite del parámetro $p$ que define cada clase y engloba los valores anteriores. Los resultados de esta operación se ofrecen en la Tabla 2.

De modo que se podría considerar únicamente el valor del parámetro $p$ de un acero dado, con el objeto de clasificarlo según su ductilidad.

Por otro lado, y siguiendo en la línea de encontrar un único parámetro que defina la ductilidad del acero, Creazza determinó el valor del área comprendida por

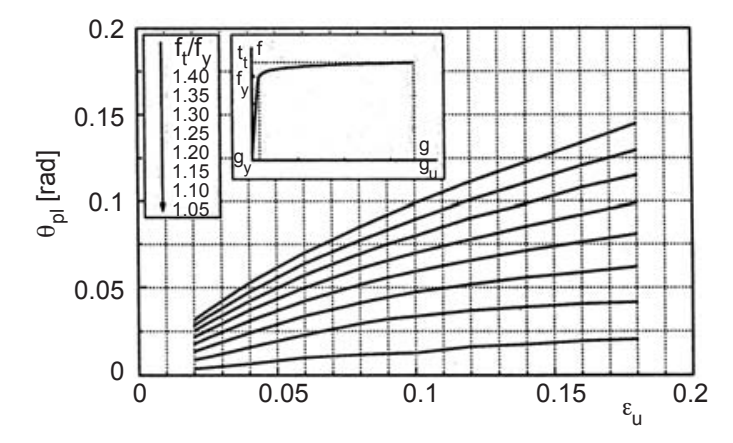

Figura 1. Resultados del análisis paramétrico para aceros sin escalón de cedencia.

Figure 1. Results of parametric analysis for steel with no definite yield point. which depends solely on the characteristics of the steel.

On the grounds of this reasoning, Cosenza et al. suggested that steel characterized by pairs of values $\left(\varepsilon_{u}\right.$ $f_{t} / f_{y}$ ) generating the same value of $p$ should be defined to be equivalent.

In the event, for instance, of a steel with no sharply defined yield point, the values of $f_{t} / f_{y}$ and $\varepsilon_{u}$ that define each CM-90 and EC-2 class of steel are used instead to compute the limit value of parameter $p$ that defines each class. The results of this operation are given in Table 2.

Consequently, the value of parameter $p$ for a given steel suffices for classification in terms of ductility.

Creazza, in turn, also seeking a single parameter to define steel ductility, determined the value of the area bounded by the following four values: yield strength,

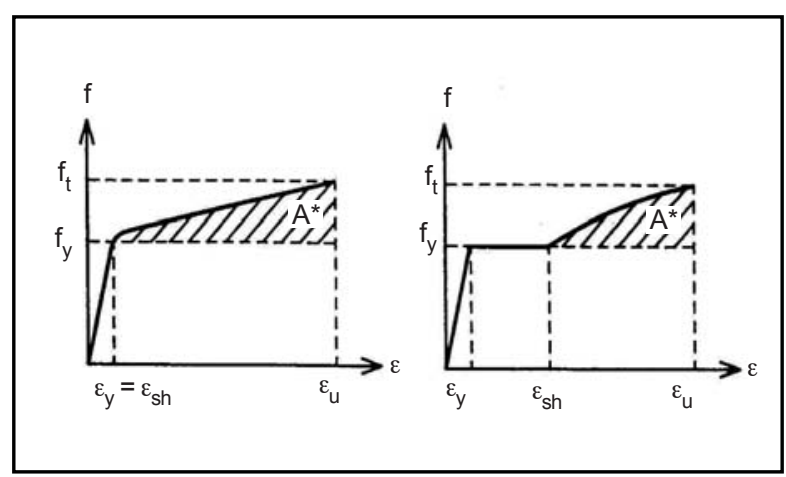

Figura 2. Diagramas de tracción para un acero sin y con escalón de cedencia.

Figure 2. Strain-stress diagrams for steel with and without a definite yield point. 
los cuatro valores siguientes: alargamiento en el límite elástico, resistencia máxima a tracción, alargamiento bajo carga máxima y tensión en el límite elástico (Figura 2).

Atendiendo a los diagramas característicos de las figuras sobre el comportamiento del acero, las áreas señaladas en la Figura 3 definen la deformación sufrida por el material durante la fase de deformación. En la opinión de estos autores estas áreas incorporan el concepto de ductilidad y proporciona un parámetro único que simultáneamente tiene en cuenta valores de tensión-deformación y, consecuentemente, puede ser usado como un indicador para establecer si un acero es aceptable en términos de ductilidad.

De este modo, se podría operar de forma similar al caso anterior y construir una tabla de valores que incorpore el nuevo parámetro definido por Creazza. En la Tabla 2 se muestran los resultados para un acero de límite elástico $500 \mathrm{~N} / \mathrm{mm}^{2}$ y sin escalón de cedencia.

Otra de las expresiones que tratan de medir directamente la ductilidad del acero agrupando en una sola variable términos de deformación y de tensión es la energía total hasta alcanzar el alargamiento bajo carga máxima, denominada tenacidad, que mide la energía por unidad de volumen absorbida por el acero durante el proceso de deformación. La energía total hasta rotura es, pues, el área encerrada bajo la curva tensión-deformación del acero (Figura 3) siendo la suma de:

A) La energía elástica, correspondiente a la superficie encerrada por la zona elástica del diagrama tensióndeformación. Esta energía se recupera en cuanto desaparece la fuerza aplicada.

B) La energía plástica, asociada a la superficie encerrada por la zona plástica del diagrama tensión-deformación comprendida entre la deformación correspondiente a una tensión igual al límite elástico del acero y la deformación bajo carga máxima del mismo. Esta energía no es recuperable, ya que va asociada a deformaciones plásticas.

Tabla 2 / Table 2

Valores del parámetro $\mathrm{p}$ y de área para cada una de las clases de ductilidad del acero

Parameter $p$ and area values for steel ductility classes

\begin{tabular}{|lccc|}
\hline & $\begin{array}{c}\text { Clase B } \\
\text { Class B }\end{array}$ & $\begin{array}{c}\text { Clase A } \\
\text { Class } \boldsymbol{A}\end{array}$ & $\begin{array}{c}\text { Clase S } \\
\text { Class S }\end{array}$ \\
\hline$\varepsilon_{\mathrm{u}}(\%)$ & 2.5 & 5 & 6 \\
\hline $\mathrm{ft}_{\mathrm{f}}$ & 1.05 & 1.08 & 1.15 \\
\hline $\mathrm{P}$ & 0.134 & 0.344 & 0.695 \\
\hline $\begin{array}{l}\text { Área }\left(\mathrm{N} / \mathrm{mm}^{2}\right) \\
\text { Area }\left(\mathrm{N} / \mathrm{mm}^{2}\right)\end{array}$ & 0.41 & 1.33 & 3 \\
\hline
\end{tabular}

ultimate tensile strength, elongation under maximum loading and elongation at the elastic limit (Figura 2).

The shaded areas marked (see Figure 3) on the typical stress-strain diagrams for steel define the deformation taking place in the material during the plastic phase. In the opinion of these authors, such areas embody the concept of ductility, constituting a single parameter that takes simultaneous account of stress and strain values and can consequently be used as an indicator to establish whether a steel is sufficiently ductile.

If operations similar to those described above were conducted, a table of values could be built for the new parameter defined by Creazza. Table 2 gives such results for a steel with a yield strength of $500 \mathrm{~N} / \mathrm{mm}^{2}$ and no definite yield point.

Another of the concepts that attempt to directly measure steel ductility by grouping stress and strain in a single variable is the total energy absorbed up to elongation at maximum loading. Known as toughness, it measures the energy absorbed by the steel per unit of volume during the deformation process. The total energy absorbed to fracture is, then, the area underneath the stress-strain curve (Figure 3) and is the sum of:

A) Elastic energy defined as the area of the elastic zone on the stress-strain curve. This energy is recovered when the force applied is removed.

B) Plastic energy, associated with the area of the plastic zone on the stress-strain curve, i.e., between yield strain and total elongation under maximum loading. This energy cannot be recovered, for it is associated with plastic deformation.

Tabla 3 / Table 3

Propiedades de ductilidad de las barras corrugadas tipo B500SD

Ductility properties of type $B 500$ SD corrugated bars

\begin{tabular}{|lcccc|}
\hline $\begin{array}{l}\text { Acero } \\
\text { Steel }\end{array}$ & $\begin{array}{c}\text { EE } \\
\left(\mathbf{N} / \mathbf{m m}^{\mathbf{2}}\right)\end{array}$ & $\begin{array}{c}\text { EP } \\
\left(\mathbf{N} / \mathbf{m m}^{\mathbf{2}}\right)\end{array}$ & $\begin{array}{c}\text { ET } \\
\left(\mathbf{N} / \mathbf{m m}^{\mathbf{2}}\right)\end{array}$ & Id \\
\hline B 500 SD & 0.625 & 30.91 & 31.53 & 50.45 \\
\hline
\end{tabular}




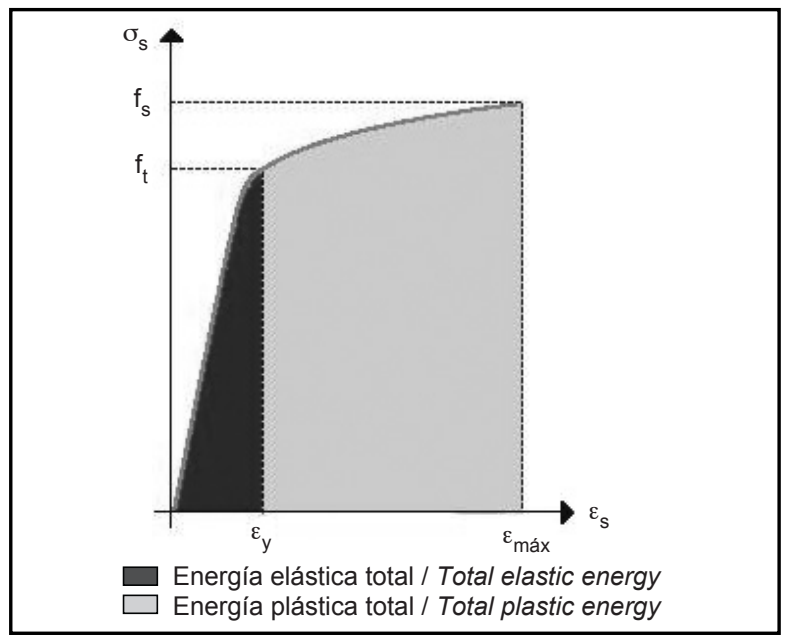

Figura 3. Energía elástica y energía plástica (11).

Figure 3. Elastic energy and plastic energy (11).

Ortega (1998) propone cuantificar la ductilidad del acero mediante un parámetro único denominado Índice de tenacidad, igual al cociente entre la tenacidad ET $=\mathrm{EE}+\mathrm{EP}$ y la energía elástica (Tabla 3). Presenta la ventaja de ser adimensional [6].
Ortega (1998) proposed to quantify steel ductility with a single parameter called the toughness index, defined as the ratio between toughness $T=E E+P E$ and elastic energy (Table 3). It has the advantage of being dimensionless [6].

$$
\mathrm{I}_{\mathrm{d}}=\frac{\mathrm{ET}}{\mathrm{EE}}=1+\left(1+\frac{\mathrm{f}_{\mathrm{s}}}{\mathrm{f}_{\mathrm{y}}}\right)\left(\frac{\varepsilon_{\text {máx }}}{\varepsilon_{\mathrm{y}}}-1\right)
$$

\section{EFECTOS DE LA CORROSIÓN EN ESTRUCTURAS DE HORMIGÓN ARMADO}

\subsection{Efecto sobre el hormigón}

Los productos derivados de la corrosión de las armaduras son más voluminosos que el acero destruido, hasta seis veces, dependiendo de la disponibilidad de oxígeno, por lo que aparecen tensiones radiales que someten a tracción al hormigón circundante (12). Si los productos de corrosión no migran a través de los poros, pequeñas cantidades de metal corroído pueden generar tensiones que superan la resistencia a tracción del hormigón. La consecuencia inmediata es la fisuración del recubrimiento de forma paralela a las armaduras.

Si el proceso no se detiene, el recubrimiento puede llegar a desprenderse, dejando al descubierto las armaduras.

La repercusión de la fisuración paralela a las armaduras y de los desprendimientos de hormigón en la capacidad mecánica de las estructuras depende de la función del elemento resistente donde se produce la corrosión.

Cuando se trata de un pilar (o en general de un elemento resistente sometido a compresión) y se llega a

\section{EFFECTS OF CORROSION ON REINFORCED CONCRETE STRUCTURES}

\subsection{Effect on concrete}

Depending on the available oxygen, the products of reinforcement corrosion may grow to a volume six times larger than the steel destroyed. The resulting radial stress subjects the surrounding concrete to tensile stress (12). If the corrosion products do not migrate through pores, small amounts of corroded metal may generate stress greater than the tensile strength of the concrete. The immediate consequence is concrete cracking along the reinforcement bars.

If the process is not halted, the concrete cover may eventually spall, exposing the reinforcement.

The impact of concrete cracking along the reinforcement and concrete detachment on the mechanical strength of structures depends on the type of member affected.

If a column (or in general any compression member) is involved and the concrete spalls, the outcome is a loss of 
desprender el hormigón, la consecuencia es la pérdida de sección resistente, proporcional a la sección desprendida, así como la disminución de la rigidez de la pieza.

Si se trata de una viga y el daño se produce en la zona traccionada, sólo es de esperar una disminución de capacidad frente a estados límites de servicio, por la pérdida de sección del hormigón situado entre fisuras, lo que da lugar, entre otros fenómenos, a mayores flechas, por la disminución del momento de inercia de la sección.

Si el daño en la viga se produce en la zona comprimida, se está en una situación similar a la del pilar, si bien en este caso existen muchas posibilidades de que el elemento tenga una mayor resistencia a compresión de la que se tuvo en cuenta en su cálculo (es habitual calcular la viga como de sección rectangular sin tener en cuenta el macizado del forjado y la capa de compresión) y el efecto de la pérdida de sección no resulte trascendente.

Antes de que aparezcan las grietas en el hormigón, se produce una reducción en la ductilidad de la sección de la viga debido a una pérdida de resistencia a compresión del hormigón que envuelve la armadura corroída como consecuencia del estado de tensiones de compresión debidas al momento flector que solicita a la viga y las tensiones de tracción producidas por la expansión de los productos de corrosión.

\subsection{Efecto sobre el acero}

Cuando la corrosión se produce de modo uniforme y el proceso es incipiente, se puede suponer, en una primera aproximación, que la capacidad mecánica de la armadura disminuye de forma proporcional a la pérdida de sección. Cuando el fenómeno está más avanzado, la existencia de picaduras, que actúan como concentradores de tensión, producen un estado de tensiones triaxial que fragiliza un material que en principio era dúctil.

En un trabajo experimental en el que se realizaron ensayos de tracción estándar con barras corrugadas de acero de dureza natural, previamente corroídas mediante un proceso acelerado, en las que se analizaron, en función del nivel de corrosión, el límite elástico $f_{y \prime \prime}$ la resistencia a tracción $f_{s}$ y la deformación bajo carga máxima $\varepsilon_{s \prime}$ se obtuvieron las siguientes conclusiones (4):

1. La influencia de la corrosión en la resistencia del acero, caracterizada por los parámetros límite elástico $f_{y}$ y resistencia a tracción $f_{s}$ es poco significativa para pérdidas de sección menores del $20 \%$. Niveles de deterioro mayores implican reducciones más importantes de $f_{y}$ y $f_{s}$, pérdidas de sección del $30-40 \%$ supusieron reducciones de $f_{y}$ del $11 \%$ y de $f_{s}$ del $8 \%$. cross-sectional strength proportional to the section detached and a decline in member stiffness.

If the member affected is a beam and the damage is caused in the area under tensile stress, all that can be expected is diminished serviceabnility limit state performance due to the loss of concrete section in the area between cracks. This gives rise, among others, to greater deflection due to the decline in the second moment of area.

If the beam is damaged in the compression area, the situation is similar to the circumstances described for columns. In this case, however, as the member may very likely have higher compressive strength than contemplated in the design (beams are usually engineered to their own rectangular section without taking account of the contribution of the slab and topping), the effect of section loss may be of minor importance.

Before the concrete cracks, ductility declines in the section affected due to a loss of compressive strength in the concrete covering the corroded reinforcement. That loss is a result of the compression stress generated by the bending moment and the tensile stress caused by corrosion product expansion.

\subsection{Effect on steel}

When corrosion is incipient and takes place uniformly, the mechanical strength of the reinforcement may be assumed to decline roughly in proportion to section loss. When the process is in a more advanced stage pits form and tend to concentrate stress, generating a state of triaxial stress that causes embrittlement of the initially ductile material.

In an experimental survey, standard tensile tests were conducted on corrugated steel bars subjected to accelerated pre-corrosion to analyze the yield strength $f_{y}$, ultimate tensile strength $f_{s}$ and elongation under maximum loading $\varepsilon_{S}$ all in relation to the degree of corrosion. The conclusions drawn were as follows (4):

1. The effect of corrosion on steel strength in terms of yield strength $f_{y}$ and ultimate tensile strength $f_{s}$ was scantly significant for section decreases of under $20 \%$. Higher degrees of deterioration entailed greater declines in $f_{y}$ and $f_{s}$ : section losses of $30-40 \%$ led to $11 \%$ lower $f_{y}$ and $8 \%$ lower $f_{s}$. 
2. Se produce una disminución sistemática de deformación bajo carga máxima $\varepsilon_{s} \mathrm{y}$, por tanto, de la ductilidad. Se obtienen reducciones de $\varepsilon_{s}$ del orden del $20 \%$ para niveles de corrosión que implican pérdidas de sección del $10 \%$ y reducciones del $45 \%$ para pérdidas de sección del 25 al 30\%.

\section{CORROSIÓN DE ARMADURAS Y DUCTILIDAD DEL ACERO}

Los estudios relativos a corrosión de armaduras en EHA son muy numerosos. Los trabajos sobre los efectos estructurales de la corrosión se cuentan en un número mucho menor y son sólo una pequeña parte de ellos los que tratan específicamente la influencia de la corrosión sobre las propiedades mecánicas del acero.

M. D. García (4) ha estudiado el efecto de la corrosión sobre el diagrama tensión-deformación del acero, sumergiendo barras de acero para armar en una disolución y forzando el paso de una corriente anódica.

M. Maslehuddin (13) ha evaluado el efecto de la corrosión atmosférica sobre las propiedades mecánicas del acero. Los dos medios en los que se han realizado las experimentaciones anteriores no representan exactamente el medio en el que se encuentra el acero de armar. A. A. Almusallam (14) ha estudiado el efecto de la corrosión sobre el diagrama tensión-deformación en barras de 6 y 12 milímetros de diámetro y límite elástico $600 \mathrm{~N} / \mathrm{mm}^{2}$.

R. Palsson (15) ha ensayado barras a tracción procedentes de la demolición de un puente de hormigón armado con su estructura corroída y ha comprobado cómo afectaban distintos grados de corrosión al diagrama tensión-deformación.

A. A. Torres (16) investigó la pérdida de capacidad portante a flexión en vigas de hormigón reforzado y la pérdida del acero debida a la corrosión localizada del refuerzo. Se observó una disminución del $20 \%$ en la resistencia a la flexión cuando la corrosión localizada fue un $14 \%$ de la pérdida de radio.

C. A. Apostolopoulos (17) realizó estudios del comportamiento mecánico de barras sometidas a un spray salino, evaluando la disminución de las propiedades mecánicas de las barras.

Sin embargo, no se han encontrado en la bibliografía trabajos lo suficientemente extensos que relacionen directamente y de forma explícita la ductilidad de aceros con su grado de corrosión, con la finalidad de analizar la posibilidad de redistribuir solicitaciones en el recálculo de estructuras construidas.
2. Corrosion systematically reduced elongation under maximum loading, $\varepsilon_{S \prime}$ and consequently ductility. These reductions were on the order of $20 \%$ for corrosion involving $10 \%$ section loss and $45 \%$ for section losses of 25 to $30 \%$.

\section{REINFORCEMENT CORROSION AND STEEL DUCTILITY}

Many studies have been published on corrosion in $R C$ structures. There are many fewer papers on the structural effects of corrosion and only a small portion of these specifically address the impact of corrosion on the mechanical properties of steel.

M.D. García (4) studied the effect of corrosion on steel stress-strain curves plotted after passing an anode current through steel reinforcing bars immersed in a solution.

M. Maslehuddin (13) evaluated the effect of air pollution on the mechanical properties of steel. The media in which the above two experiments were conducted do not accurately reproduce the environment surrounding reinforcing steel. A. A. Almusallam (14) studied the impact of corrosion on the stress-strain diagram for 6- and 12-millimetre bars with a yield strength of $600 \mathrm{~N} / \mathrm{mm}^{2}$.

R. Palsson (15) tensile tested bars taken from demolition rubble from a corroded reinforced concrete bridge and analyzed the effect of different degrees of corrosion on the stress-strain curve.

A. A. Torres (16), exploring the loss of flexural carrying capacity in reinforced concrete beams and the loss of steel due to localized corrosion, reported a $20 \%$ decline in bending strength for radius losses of $14 \%$.

C.A. Apostolopoulos (17) subjected bars to saline spray to assess the decline in their mechanical strength.

Nonetheless, the literature is wanting in sufficiently extensive papers directly and explicitly relating steel ductility to the degree of corrosion to establish the grounds for possible moment redistribution when re-engineering standing structures. 


\subsection{Objetivos}

En este trabajo experimental se determina, en función del grado de corrosión, las propiedades de tensión y de deformación del acero de armar, y se aplican los criterios propuestos por los distintos autores mencionados sobre los requisitos de ductilidad, para establecer una relación entre el grado de corrosión y los valores obtenidos y así poder decidir sobre la posibilidad de redistribuir solicitaciones en estructuras sobre las que haya que intervenir.

\subsection{Proceso experimental}

Se han fabricado losas de hormigón amasadas con un $2 \%$ de ión cloruro en peso de cemento. Las variables a tener en cuenta son:

- Disposición de la armadura en la masa del hormigón. Se toman como variables el recubrimiento y la separación entre barras.

- Calidad del hormigón. Se fabrican tres tipos de hormigón que se usan con distintos fines en construcción.

- Diámetro de la armadura. Se analizan dos diámetros: 16 y $20 \mathrm{~mm}$.

En este trabajo se presentan los resultados obtenidos en la primera fase, correspondiente a una losa confeccionada con hormigón para estructuras ejecutadas in situ (H-25), el tipo de acero es B500 SD, 6 barras de diámetro $16 \mathrm{~mm}$. Separación entre barras y recubrimiento $5 \mathrm{~cm}$ (Tabla 4).

Para realizar el proceso de corrosión acelerada de las armaduras y estudiar posteriormente la variación de las propiedades de ductilidad del acero, las barras se han cortocircuitado externamente y entre ellas y una plancha de plomo, colocada sobre la superficie de las losas de hormigón, se ha hecho pasar una corriente anódica constante.

\subsection{Resultados}

Una vez fisurado el hormigón, se han extraído las barras y tras la eliminación del óxido formado por decapado químico, se ha determinado el grado de corrosión producido a cada una de ellas y se han ensayado a tracción (Tabla 5), obteniendo datos necesarios para evaluar la ductilidad del acero según distintos criterios (Tabla 6).

\subsection{Objectives}

This experimental survey determines the stress and strain properties of reinforcing steel when subjected to corrosion. The criteria on ductility requirements proposed by the authors mentioned above are applied to establish the relationship between the degree of corrosion and the stress and strain values found and ascertain on that basis whether moments may be redistributed in structures in need of intervention.

\subsection{Experimental procedure}

Concrete slabs with a $2 \%$ chloride ion content by weight of cement were prepared. The variables considered were:

- Positioning of the reinforcement in the concrete, defined in terms of cover and spacing between bars.

- Concrete quality. Three types of concrete were prepared, all used commercially for different construction purposes.

- Reinforcement diameter. Two diameters were analyzed: 16 and $20 \mathrm{~mm}$.

This paper discusses the results obtained in the first phase for a slab made with concrete for "in situ" structures (Spanish concrete class H-25). The slab was reinforced with six 16-mm B500 SD quality steel bars, spaced at 5-cm intervals and with a 5-cm cover (Table 4).

To study corrosion-mediated variation in steel ductility properties, the bars were short-circuited externally by passing a constant anode current between the steel and a lead plate set on top of the concrete slabs.

\subsection{Results}

The bars were withdrawn from the slab after the concrete cracked and chemically cleaned to remove the rust and determine the degree of corrosion. Tensile tests (Table 5) were then conducted and the findings used to assess steel ductility in accordance with the various criteria (Table 6).

Tabla 4 / Table 4

Características mecánicas mínimas garantizadas para aceros de Tipo B 500 SD Minimum guaranteed mechanical characteristics of Type B 500 SD steel

\begin{tabular}{|lcccccc|}
\hline Acero / Steel & $\mathbf{R}_{\mathbf{e}}(\mathbf{M P a})$ & $\mathbf{R}_{\mathbf{m}} \mathbf{M P a}$ & $\mathbf{R}_{\mathbf{e}}$ real/ $\mathbf{R}_{\mathbf{e}}$ nominal & $\mathbf{A}_{\mathbf{5}} \%$ & $\mathbf{A}_{\mathbf{g t}} \%$ & $\mathbf{R}_{\mathbf{m}} / \mathbf{R}_{\mathbf{e}}$ \\
\hline B500SD & 500 & 575 & $\leq 1.25$ & $\geq 16$ & 8 & $\geq 1.15 ; \leq 1.35$ \\
\hline
\end{tabular}


Tabla 5 / Table 5

Resultados del ensayo de tracción

Tensile test results

\begin{tabular}{|l|c|c|c|c|c|c|c|c|}
\hline Barra / Bar $\phi=16$ & $\mathbf{f}_{\mathbf{s}}$ & $\mathbf{f}_{\mathbf{y}}$ & $\mathbf{f}_{\mathbf{s}} / \mathbf{f}_{\mathbf{y}}$ & $\mathbf{A}_{\mathbf{5}} \mathbf{f}$ & $\mathbf{2 . A}_{\mathbf{8}}-\mathbf{A}_{\mathbf{4}}$ & $\mathbf{A}_{\mathbf{5}}$ & $\varepsilon_{\mathbf{u}} \mathbf{\%}$ & $\varepsilon_{\mathbf{m a x}} \mathbf{\%}$ \\
\hline 1 & 599.9 & 483.3 & 1.24 & 9.4 & 13.6 & 5.4 & 17.5 & 8 \\
\hline 2 & 547.9 & 424.1 & 1.29 & 9.6 & 14.1 & 5.2 & 20 & 4 \\
\hline 3 & 568.8 & 447.2 & 1.27 & 9.4 & 13.7 & 5.3 & 17.5 & 6 \\
\hline 4 & 572.3 & 445.5 & 1.28 & 9.5 & 13.9 & 5.2 & 18.75 & 4 \\
\hline 5 & 569.8 & 458.5 & 1.24 & 9.1 & 13.4 & 5.3 & 13.75 & 6 \\
\hline 6 & 578.4 & 460.7 & 1.26 & 9.5 & 13.9 & 5.3 & 18.75 & 6 \\
\hline R-16 & 639.2 & 533.05 & 1.2 & 10 & 14.6 & 5.7 & 0.27 & 14 \\
\hline
\end{tabular}

Tabla 6 / Table 6

Resultado parámetros de ductilidad y grado de corrosión alcanzado por cada barra Bar ductility parameters and degree of corrosion

\begin{tabular}{|l|c|c|c|c|c|c|c|}
\hline Barra / Bar & $\mathbf{\%}_{\text {corr }}$ & $\mathbf{f}_{\mathbf{s}} / \mathbf{f}_{\mathbf{y}}$ & $\varepsilon_{\max } \mathbf{\%}$ & $\varepsilon_{\mathbf{u}} \mathbf{\%}$ & $\mathbf{p}$ & $\mathbf{I d}$ & Área / Area \\
\hline 1 & 14.3 & 1.24 & 8 & 0.24 & 1.31 & 72.96 & 6.22 \\
\hline 2 & 18 & 1.29 & 4 & 0.21 & 1.07 & 41.94 & 3.30 \\
\hline 3 & 7 & 1.27 & 6 & 0.22 & 1.17 & 59.69 & 4.86 \\
\hline 4 & 6 & 1.28 & 4 & 0.22 & 0.89 & 39.74 & 3.38 \\
\hline 5 & 6 & 1.24 & 6 & 0.23 & 1.06 & 57.46 & 4.45 \\
\hline 6 & 5.7 & 1.26 & 6 & 0.23 & 1.14 & 57.49 & 4.71 \\
\hline R- $\varnothing 16$ & 0 & 1.20 & 14 & 0.27 & 1.70 & 114.36 & 9.90 \\
\hline
\end{tabular}

\subsection{Discusión de resultados}

El diagrama de tracción de la barra de referencia muestra el escalón de cedencia del acero mientras que en los diagramas de tracción de las barras corroídas el escalón desaparece.

El cociente entre la tensión de rotura y la tensión en el límite elástico que es uno de los parámetros habitualmente empleados para medir la ductilidad del acero no se ve significativamente afectado por la corrosión, es más, en muchos casos aumenta con el grado de corrosión. Esto, que en un primer momento se podía juzgar como beneficioso, hay que tomarlo con precaución en zonas sísmicas. Recuérdese que en zona sísmica se limita superiormente el valor del cociente a 1,35 para impedir que la redistribución de efectos pudiera dar lugar a solicitaciones normales o cortantes que superasen el límite de la estructura, produciéndose una rotura de tipo frágil.

Tal y como se puede comprobar en los datos obtenidos, la corrosión es más sensible a los efectos de deformación que a efectos de tensión. Los valores de alargamiento bajo carga máxima han disminuido de forma notable, llegando en algunos casos a perderse más de la mitad del alargamiento experimentado por la barra patrón.

En el caso de las barras 2 y 4 el alargamiento es inferior al $5 \%$ exigido por el Eurocódigo 2 y el Código Modelo

\subsection{Discussion}

The stress-strain diagram for the reference bar exhibited a clearly defined yield point that was not found on the curves for the corroded bars.

The ratio between ultimate and yield strength, one of the parameters generally used to measure steel ductility, was not significantly affected by corrosion. Indeed, in many cases it increased with the degree of corrosion. While this may initially appear to be beneficial, it should be viewed with caution in seismic areas. In such zones, the ratio is limited to an upper value of 1.35 to prevent moment redistribution from raising normal or shear stress above the limits the structure is able to bear, a situation that would lead to fragile fracture.

As the data obtained show, corrosion is more sensitive to strain than to stress. The values of elongation under maximum loading declined substantially, in some cases to less than half of the elongation recorded for the control.

Elongation in bars 2 and 4 was lower than the 5\% required by Eurocode 2 and the Model Code to be 
para poder considerar el acero como de alta ductilidad y poder llegar a redistribuciones de hasta el $30 \%$. Sin embargo, en ambas barras se supera el valor exigido por estos documentos del otro parámetro, cociente entre la tensión de rotura y la tensión en el límite elástico. Es aquí donde toma interés el concepto de acero equivalente que tiene en cuenta ambos parámetros para clasificar los aceros según su ductilidad.

\section{CONCLUSIONES}

Se aprecia una variación en el trazado de la curva resultante del ensayo de tracción de las barras corroídas en cuanto a que se observa la pérdida del escalón de cedencia, mostrando un diagrama similar al de los aceros obtenidos por deformación en frío.

La deformación bajo carga máxima es muy sensible a la corrosión disminuyendo de forma drástica su valor. En algún caso no se alcanza el 5\%, límite de algunos documentos para considerar al acero como de alta ductilidad.

En esos casos, tomando por ejemplo el criterio de Cosenza, basado en la capacidad de rotación plástica de la sección, las barras mencionadas podrían considerarse como de alta ductilidad. Al mismo resultado se llega con el criterio de Creazza, que tiene en cuenta la parte del área limitada por el diagrama tensión-deformación de la barra ensayada. Incluso las barras a las que nos referimos ( 2 y 4), podrían considerarse de alta ductilidad siguiendo los criterios anteriores, lo que supone la posibilidad de poder calcular la estructura con altos niveles de redistribución de solicitaciones.

Los valores de índice de ductilidad de dichas barras, sin embargo, quedan ligeramente por debajo del mínimo exigido para considerarlos como de características especiales de ductilidad. Este parámetro (Id) es, por tanto, más exigente que los demás a este efecto. Se considera la necesidad de continuar realizando más ensayos que permitan, una vez interpretados, llegar a unas conclusiones definitivas al respecto. classified as high ductility steel and accommodate up to $30 \%$ redistribution. Nonetheless, both bars exceeded the value required by these standards for the other parameter, the ratio between ultimate and yield strength. It is in such cases that the equivalent steel concept, i.e., the ability to consider both parameters to determine steel ductility, is particularly relevant.

\section{CONCLUSIONS}

The shape of the tensile test curve for corroded bars differed from the curve for the control bar in that, like diagrams for cold-formed steel, they lacked a well defined yield point.

Elongation under maximum loading was observed to be highly sensitive to corrosion, declining drastically in corrodes reinforcement. In two cases it was under the 5\% minimum requirement for high ductility laid down in some standards.

In such cases, under the Cosenza criterion, for instance, based on plastic rotation capacity in the section, these bars would be regarded to exhibit high ductility. The same result is reached if the Creazza criterion is applied, in which ductility is defined in terms of part of the area under the stress-strain curve for the bar tested. Under such criteria, even the bars referred to here ( 2 and 4) could be regarded to be highly ductile and the structure in question could be re-engineered assuming high levels of moment redistribution.

Bar ductility was, however, slightly lower than the minimum required for special ductility steel. This parameter (Id) is, therefore, somewhat more demanding than the others in this regard. A need is identified for further testing to corroborate the preliminary conclusions discussed hereunder.

\section{BIBLIOGRAFÍA / BIBLIOGRAPHY}

(1) Ortega Valencia, H.: Estudio experimental de la influencia del tipo de acero en la capacidad de redistribución en losas de hormigón armado. Tesis doctoral. ETS de Ingenieros de Caminos, Canales y Puertos, Universidad Politécnica de Madrid, 1998.

(2) Doñate Megías, A.: Cálculo práctico de estructuras de hormigón con redistribución limitada de esfuerzos, Calidad Siderúrgica S.R.L., Madrid, 2003.

(3) Cobo Escamilla, A., León, J.: "Ductilidad seccional de estructuras de hormigón armado cuando se tienen en cuenta el confinamiento y el sobrearmado", Anales de Ingeniería Mecánica, Revista de la Asociación Española de Ingeniería Mecánica, no 2 (1997), pp. 97-106. (4) García, M. D., Alonso, M. C., Andrade, M. C. y Rodríguez, J.: "Influencia de la corrosión en las propiedades mecánicas del acero", Hormigón y Acero, no 210 (1998), pp. 11-21.

(5) Código Modelo CEB-FIP 1990 para Hormigón Estructural. Comité Euro-Internacional del Hormigón y federación Internacional de pretensado. CEB Boletín de información 213/214 mayo, 1993. 
(6) Eurocódigo EC-2 (prEN-1992-1-1): "Proyecto de estructuras de Hormigón".

(7) Instrucción para el Hormigón estructural (EHE). Comisión Permanente del Hormigón, $2^{a}$ Ed. Madrid. Ministerio de Fomento, Centro de Publicaciones, 1998.

(8) UNE 36065:2000 Ex.: "Barras corrugadas de acero soldable con características especiales de ductilidad para armaduras de hormigón armado", Madrid, 2000.

(9) Cosenza, E., Greco, C. y Manfredi, G.: "An Equivalent steel Index in the Assessment of ductility Performances of the Reinforcement", CEB Boletín, no 242 (1998).

(10) Creazza, G. y Russo, S.: "A new proposal for defining the ductility of concrete reinforcement steels by jeans of a single parameter", CEB Boletín, 242 (1998).

(11) Comisión asesora ARCER: Aceros con características especiales de ductilidad para hormigón armado, Calidad Siderúrgica. Monografía 1, Madrid, 2000.

(12) Cascudo, O. y Helene, P.: "Comportamiento mecánico del hormigón de recubrimiento frente a los productos de corrosión de armaduras", Hormigón y Acero, no 214 (1999), 40 trimestre.

(13) Maslehuddin, M., Al-Zahrani, Al-Dulaijan, M. M., Abdulquddus, S. U., Rehman, S. y Ahsan, S. N.: "Effect of steel manufacturing process and atmospheric corrosion on the corrosion resistance of steel bars in concrete", Cement and Concrete Composites, n० 24 (2002), pp. 151-158.

(14) Almusallam, A. A.: "Effect of degree of corrosion on the properties of reinforcing steel bars", Construction and Building Materials, 15 (2001), pp. 361-368.

(15) Palsson, R. y Mirza, M. S.: "Mechanical response of corroded steel reinforcement of abandoned concrete bridge", ACI Structural Journal, no 99 (2) 2002, pp. 157-162.

(16) Torres-Acosta, A. A., Martínez-Madrid, M. y Muñoz-Noval, A.: "Capacidad remanente en vigas de hormigón que presentan corrosión localizada en el acero de refuerzo", Mater. Construcc., vol. 53, no 271-172 (2003).

(17) Apostolopoulos, C. A., Papadopoulos, M. P. y Pantelakis, S.: "Tensile behavior of corroded reinforcing steel bars BSt 500s", Construction and building Materials, no 20 (2006), pp. 782-789. 